\title{
Contribuição de melhoria e o estado de direito ambiental: uma nova abordagem a partir do exame da situação do Parque Augusto Franco em Aracaju
}

\author{
Improvement Contribution and the state of \\ environmental law: a new approach by examining the \\ situation of Parque Augusto Franco in Aracaju
}

\author{
Wallace Souza Barbosa* \\ Roberto Rodrigues de Souza** \\ Jussara Moreno Jacintho***
}

\section{Resumo}

A contribuição de melhoria é uma espécie de tributo cujo fato gerador é a valorização imobiliária decorrente de obras públicas. A apropriação capitalista do uso e ocupação do solo urbano contribui para a segregação socioespacial e o desequilíbrio na distribuição dos benefícios e ônus ambientais e de se viver e habitar na urbe, afetando o direito de acesso à cidade como um todo. Uma relação homem-natureza em descompasso com o meio ambiente ecologicamente equilibrado do qual a qualidade de vida é a essência. Essas distorções podem ser mitigadas através da contribuição de melhoria - instrumento urbanístico tributário -, na medida em que viabiliza a redistribuição de renda. A partir de uma interpretação ampliada do conceito de obras públicas e da multiplicidade de ocorrência do fato gerador do referido tributo, traça-se uma nova abordagem da

Mestre em Desenvolvimento e Meio Ambiente - PRODEMA/UFS, é professor efetivo da Universidade Federal de Sergipe - UFS, no Departamento de Ciências Contábeis. Aracaju - SE - Brasil. Email: souzafisc@hotmail.com

** Doutor em Engenharia Química (UNICAMP/SP). Realizou pós-doutoramento no Centro de Engenharia Biológica e Química (BERG) do Instituto Superior Técnico da Universidade Técnica de Lisboa, Portugal, com estudos adicionais na Universidade de Birminghan, Inglaterra (19992000). Atualmente é Professor Associado da Universidade Federal de Sergipe. Aracaju - SE Brasil. Email:rrsouza.br@gmail.com

*** Doutora em Direito Constitucional (PUC/SP). Mestre em Direito (UERJ/RJ). Atualmente é professora adjunta de Direito Constitucional do Departamento de Direito da Universidade Federal de Sergipe. Aracaju - SE - Brasil. Email: j.jacintho@uol.com.br 
contribuição de melhoria, tendo como fundamento teórico-legal a Constituição Federal de 1988 e o Estado de Direito Ambiental, que tem como marco jurídico a solidariedade e como marco axiológico a sustentabilidade.

Palavras-chave: Contribuição de melhoria. Estado de Direito Ambiental. Manutenção de obras públicas.

\section{Abstract}

The Improvement Contribution is a kind of tribute whose taxable event is the real estate valuation resulting from public works. The capitalist appropriation of urban land use and occupation contribute to socio-spatial segregation and imbalance in the distribution of benefits and environmental burden and to live and dwell in the metropolis, affecting the right of access to the city as a whole. A relationship man and nature out of step with the environment ecologically balanced which the quality of life is the essence. These distortions can be mitigated through the Improvement Contribution - Tax urban instrument - to the extent that enables the redistribution of income. From an augmented interpretation of the concept of public works and the multiplicity of the taxable event of that tax, we draw a new approach Improvement Contribution, with the theoretical and legal foundations to the 1988 Federal Constitution and the rule of law Environmental whose legal framework solidarity and as a landmark axiological sustainability.

Keywords: Improvement Contribution. State Environmental Law. Maintenance of public works.

\section{Introdução}

O processo de compatibilização entre a necessidade de consumo de recursos naturais exigida pelo desenvolvimento econômico e a imprescindibilidade ainda maior de preservação do meio ambiente ganham relevo nos dias atuais, dada a escassez dos referidos recursos. Além disso, o crescimento populacional e o modelo de sociedade pautado nos padrões capitalistas de desenvolvimento industrial e tecnológico contribuem tanto para a urbanização quanto para o agravamento das desigualdades sociais nas cidades. 
Sachs (2008), ao diferenciar crescimento (aspectos quantitativos) de desenvolvimento (elementos qualitativos), defende que este último seja "ambientalmente sustentável, economicamente sustentado e socialmente includente". E lamenta:

Infelizmente, o crescimento econômico promovido pelas forças do mercado traz, mesmo quando bem-sucedido em nível econômico, resultados sociais opostos aos almejados: as diferenças sociais aumentam, a riqueza se concentra na mão de uma minoria, com marginalização simultânea de uma parcela importante da população. (SACHS, 2008, p. 118)

$\mathrm{Na}$ capital sergipana, essa marginalização é evidenciada pela segregação espacial entre classes sociais de poderes aquisitivos diferentes, em que áreas de alto status se localizam próximas a regiões com privilégios naturais (FRANÇA, 2005). Entretanto, "a prioridade do uso dos bens ambientais não implica exclusividade de uso" (MACHADO, 2003, p. 51).

Sendo assim, a depender da dinâmica de mercado, o usufruto de bens ou serviços ecossistêmicos pode significar a marginalização de certas classes socais quando tal fruição está acessível exclusivamente às classes com maior poder aquisitivo. "A valorização econômica dos recursos naturais não pode ser admitida para excluir faixa da população de baixa renda." (MACHADO, 2003, p. 53).

Dessa forma, e tendo como marcos teórico-legais a contribuição de melhoria e a Constituição Federal de 1988, a partir do Estado de Direito Ambiental (BELCHIOR, 2011; CANOTILHO, 2001; CANOTILHO e LEITE, 2007; HARTMANN, 2010), verifica-se que a contribuição de melhoria pode ser um instrumento mitigador de distorções socioambientais processada na relação entre o homem e a natureza, tomando-se como proposição de referência para análise a região de entorno do Parque Augusto Franco, em Aracaju-SE1.

O Parque Augusto Franco influencia entre $5,46 \%$ e $20,74 \%$ o preço médio de oferta dos apartamentos localizados nas proximidades do parque. (BARBOSA, 2014). 
A contribuição de melhoria vem comumente sendo admitida juridicamente nos casos de valorização decorrentes da construção física de parques, cuja receita de tal tributo é destinada exatamente ao custeio desses empreendimentos. Entretanto, com a evolução dos debates sobre a problemática ambiental e, por conseguinte, do Direito Ambiental, admite-se a possibilidade de tais receitas serem destinadas ao custeio da manutenção (e não somente da construção) dos parques públicos, com base em interpretação conforme a Constituição Federal, o que caracterizaria a contribuição científica desse estudo.

\section{0 meio ambiente e a Constituição Federal de 1988}

Apesar de criticar a expressão "meio ambiente", por entendêla redundante, Silva (2004) classifica o meio ambiente em artificial, cultural, natural e do trabalho. O artificial é o espaço urbano construído pelo homem. O cultural é o patrimônio histórico, artístico, arqueológico, paisagístico etc. O natural é o meio ambiente físico, composto por solo, água, ar atmosférico etc. Por fim, o do trabalho é o local onde se desenvolve a atividade do trabalhador, pautada pelas condições de segurança e salubridade.

Para Milaré (2009, p. 118), a Lei n 6.938/81 “[...] ampliou acertadamente o conceito de meio ambiente, não o atando exclusivamente aos meros recursos naturais, levando em conta, ao revés, inclusive, o ecossistema humano". Em semelhança ao pensamento de Milaré (2009), a pesquisadora Flávia Moreira Guimarães Pessoa (2013, p. 7) traz um ponto de vista esclarecedor, a saber:

A ecologia não tem a ver apenas com a natureza [ecologia natural], mas principalmente com a sociedade e a cultura [ecologia humana, social etc.]. Dentro desta visão, toda existência é coexistência, subsistindo através de uma teia infinita de relações ominicompreensivas.

Não há como considerar a natureza (flora, fauna, ar, água, solo etc.) dissociada do homem, até porque um é parte do outro e vice-versa, numa teia de relações complexas e imbricadas entre si. Nesse sentido: 
Tanto na atividade cotidiana como na interpretação do texto jurídico, a metodologia a ser adotada é aquela capaz de visualizar a gama de relações humanas envolvidas. Uma vez inserida na sociedade, natureza deixa de ser algo em si, tornando-se indissociável do todo social. (DERANI, 1997, p. 111).

Portanto, o meio ambiente é formado pelo ecossistema natural, pelo ecossistema humano e pela relação entre eles. Entretanto, tais conceitos acerca do meio ambiente foram construídos ao longo do tempo, sendo a Política Nacional do Meio Ambiente (PNMA) instituída pela Lei $n^{\circ} 6.938 / 81$, o marco legal transitório no Brasil em direção a um novo paradigma acerca do tratamento das questões socioambientais no âmbito da ordem jurídica brasileira.

O início desta mudança paradigmática no ordenamento jurídico brasileiro é marcado pela edição da Lei 6.938/81, que instituiu a Política Nacional do Meio Ambiente. Esse texto legal definiu conceitos gerais, estabeleceu diretrizes, objetivos e fins para a proteção ambiental. Abandonou o paradigma ético antropocêntrico e adotou uma visão holística [ecossistêmica] do meio ambiente, na qual o ser humano é uma das partes integrantes. (PESSOA, 2013, p. 7)

Essa nova e ampliada concepção do meio ambiente, que repercute na nova ordem constitucional de 1988, é fruto da própria evolução das ciências frente às questões envolvendo o homem e a natureza. As revoluções científicas, a partir de novas referências paradigmáticas (KUHN, 1998; SANTOS, 2009), bem como a crítica e autocrítica dos cientistas quanto ao reconhecimento da falibilidade humana (POPPER, 1982) e, por isso, catalisadora de métodos científicos mais rígidos ${ }^{2}$, são

2 "A utilização do método popperiano vem a contribuir nos esforços da ciência para estudar a influência e os impactos das atividades humanas sobre o meio ambiente e a forma como este mantém relações interativas em escala local, regional e planetária. Para então, buscar formas eficientes e eficazes de harmonizar o desenvolvimento e a preservação da biodiversidade, proporcionando condições e oportunidades de vida iguais para as gerações futuras." (FEITOSA e SOUZA, 2012, p. 90). 
resultado, em última análise, dos problemas e riscos ${ }^{3}$ causados pela própria atividade humana, mas que, da necessidade de se encontrar soluções, acabam desencadeando o avanço científico.

Essa (r)evolução não é diferente na ciência do Direito, que, a partir de objetivos, princípios e instrumentos da política brasileira sobre a área ambiental, inspirados na Constituinte de 1988, vislumbra um novo formato teórico, ou melhor, um novo olhar sobre o arcabouço jurídico constitucional, no tocante às relações envolvendo o meio ambiente. $O$ fio condutor para essa alvissareira trilha, em alguma medida rompedora de paradigmas interpretativos, perpassa pelos princípios constitucionais ambientais insertos na Carta Magna. Assim, nesse momento em que se inicia a construção argumentativa sobre as bases jurídicas em que está alicerçado o Estado brasileiro, convém fazer a distinção entre valor, norma, princípio e regra. Referindo-se às ideias de norma e princípio,

[...] não há distinção entre princípios e normas, os princípios são dotados de normatividade, as normas compreendem regras e princípios, a distinção relevante não é, como nos primórdios da doutrina, entre princípios e normas, mas entre regras e princípios, sendo as normas o gênero, e as regras e os princípios a espécie. (BONAVIDES, 1999, p. 259)

Segundo Alexy (2011), os princípios são normas que ordenam a realização de algo na maior medida possível. Já as regras são normas que ou são satisfeitas ou não são satisfeitas. Enquanto os princípios são mandamentos de otimização, as regras são mandamentos de definição. O próprio Alexy (2011) ainda faz uma distinção entre valor e princípio.

Aquilo que, no modelo de valores, é prima facie o melhor é, no modelo de princípios, prima facie devido [...] Se se pressupõe a possibilidade dessa transição, então, é perfeitamente possível, na argumentação jurídica, partir de um modelo de valores em vez de partir de um modelo

3 Trata-se da Sociedade de Risco abordada por Ulrich Beck (2011, p. 96), segundo o qual "O processo de modernização torna-se 'relexivo', convertendo-se a si mesmo em tema e problema". 
de princípios. Mas o princípio tem a vantagem de que nele o caráter deontológico do direito se expressa claramente. (ALEXY, 2011, p. 152-153)

Portanto, grosso modo, poderia ser considerado o seguinte: o melhor a ser observado no constructo teórico acerca do Estado brasileiro tem relação com o valor (conceito axiológico); a maior medida possível para que o "dever-ser" seja respeitado vincula-se aos princípios (conceito deontológico); e a definição objetiva da materialização do referido constructo teórico diz respeito às regras. Por isso, o que se busca é o alinhamento desses três conceitos, sendo que, em caso de conflito entre as regras, exclui-se uma em detrimento da outra, e em se tratando de colisão entre princípios, pondera-se a observância de um em prevalência de outro, no sentido de otimizar a medida em direção ao melhor (valor) a ser seguido. Torna-se importante, porém, registrar que:

[...] já se discute tanto a aplicação do esquema tudo ou nada para os princípios como a possibilidade de também as regras serem ponderadas. Isso porque, como visto, determinados princípios - como o princípio da dignidade da pessoa humana e outros - apresentam um núcleo de sentido ao qual se atribui natureza de regra, aplicável biunivocamente. Por outro lado, há situações em que uma regra, perfeitamente válida em abstrato, poderá gerar uma inconstitucionalidade ao incidir em determinado ambiente, ou ainda, há hipóteses em que a adoção do comportamento descrito pela regra violará gravemente o próprio fim que ela busca alcançar. (BARROSO, 2007, p. 357-358)

Atento à dinâmica social, o caráter dialógico do Direito permitiu que se evoluísse, de início, para um caráter normativo dos princípios, e agora para uma fase com uma objetividade e uma concretude tais quais as regras (tudo ou nada). Esse avanço ganha relevo principalmente quando se observa que princípios antes prescritos em lei (Lei $n^{\circ}$ 6.938/81) são objeto de tratamento pela Carta Maior de um país. É o que se verá adiante. 


\section{Princípios constitucionais do Direito Ambiental}

O conteúdo da Lei $n^{\circ} 6.938$, de 1981, teve sua origem histórica em 1972, com a Declaração de Estocolmo, na $1^{\text {a }}$ Conferência da ONU sobre o Meio Ambiente. Silva (2004, p. 212), contudo, critica a disposição legislativa do referido diploma legal, ao entender que "A diferença entre princípios e objetivos da Política Nacional do Meio Ambiente não é bem caracterizada na Lei n 6.938, de 1981". Na mesma linha, Milaré (2009) observa que a formulação dos princípios na comentada lei restou ambígua, ou por falta de assessoria legislativa ou em razão de a matéria ser novidade para a sociedade, sendo que vários itens são, na realidade, programas, metas ou modalidades de ação.

Em todo caso, caracterizando-se como objetivo geral, específico ou como princípio, a mens legis foi pontuada e serviu de inspiração para os princípios constitucionais do Direito Ambiental. Nesse sentido, tomandose como referência o elenco adotado por Milaré (2009) e a dicção do artigo 225 da CRFF $/ 88^{4}$, analisamos apenas três dos princípios voltados ao campo ambiental constantes da alusiva Carta Política, fazendo-se a correlação com a PNMA.

2.1 Princípio do meio ambiente ecologicamente equilibrado como direito fundamental da pessoa humana

O artigo $4^{\circ}$, inciso I, da Lei $\mathrm{n}^{\circ} 6.938 / 81^{5}$ faz menção a esse princípio, havendo autores, em minoria, que entendem que o direito ao meio ambiente não é um direito fundamental. Hartman sintetiza os argumentos dos filiados a esse posicionamento:

Reconhecendo que uma vasta maioria da doutrina entende que o art. 225 da Constituição Federal brasileira contém norma de direito fundamental, ousamos discordar. A nosso

"Todos têm direito ao meio ambiente ecologicamente equilibrado, bem de uso comum do povo e essencial à sadia qualidade de vida, impondo-se ao Poder Público e à coletividade o dever de defendê-lo e preservá-lo para as presentes e futuras gerações." (BRASIL, 1988).

5 Art. $4^{\circ}$ - A Política Nacional do Meio Ambiente visará: 
ver, o primeiro argumento, de fundo político e filosófico, restou suficientemente exposto: uma norma de direito fundamental ao meio ambiente não se coaduna com o reconhecimento de um valor intrínseco da natureza. O segundo argumento é um de natureza técnico-jurídica: sob o ponto de vista do direito constitucional, a proteção ambiental por meio de uma norma objetiva é mais adequada e operacionalizável que por meio de um direito fundamental. (HARTMAN, 2010, p. 39)

Quanto ao primeiro argumento, Hartman entende que os direito fundamentais são sempre individuais ou no mínimo individualizáveis, a exemplo do direito à vida, à saúde, à liberdade etc., pertencente, portanto, a ele, indivíduo. Tratar o direito ao meio ambiente ecologicamente equilibrado como direito fundamental seria torná-lo objeto de uma demanda individual, quando na verdade a proteção ambiental está ligada ao bem comum.

Nesse ponto, continua o autor, haveria uma incongruência dos direitos fundamentais - os quais, numa visão antropocêntrica do meio ambiente, são individualistas - com o valor intrínseco da natureza, que se relaciona com uma perspectiva ecocêntrica do ambiente, nela incluída a proteção aos direitos dos animais e seres vivos como um todo. Ou seja, haveria, no fundo, um problema de titularidade, pois se os direitos fundamentais são objeto de uma demanda individual judicializável, a quem caberia o direito subjetivo de ação contra lesão aos direitos dos demais seres vivos? E mais - continua indagando o autor -, mesmo que se admita uma visão antropocêntrica da natureza, a quem pertenceria a titularidade de demanda subjetiva de um direito fundamental ao meio ambiente no caso concreto de lançamento de produtos químicos no rio Amazonas: aos habitantes da margem do rio? Apenas aos habitantes dos estados da Federação pelos quais corre o rio? Aos brasileiros ou apenas aos brasileiros? Para enfeixar o argumento inicial, Hartman (2010, p. 37) leciona:

Afirmar que não há um direito fundamental ao meio ambiente não significa, entretanto, que o indivíduo jamais 
terá uma posição frente ao Estado cujo objeto seja a proteção ambiental. Essa posição pode surgir, na forma de direito subjetivo, porém não será fundamental.

Avança o autor, dessa forma, para o segundo argumento, no qual defende que a proteção ambiental seja tratada não como um direito fundamental, mas como objetivo estatal, em que a vinculação dos deveres dos particulares face à responsabilidade ambiental possa ser objeto de matéria do Legislativo, através de normas infraconstitucionais a serem cumpridas pelo Executivo e as demandas julgadas, pelo Judiciário. A opção de compreender o meio ambiente como direito fundamental acaba por restringir os bens ambientais protegidos, dado que fica na esfera subjetiva do indivíduo.

Ademais, Hartman (2010, p. 40) defende que "a noção de direitos difusos é apenas uma forma de contornar esse problema - no fundo uma questão de titularidade, já mencionada - mas, entendemos que não é a melhor solução do ponto de vista da técnica constitucional".

Por outro viés, a professora portuguesa Carla Amado Gomes, ao não ser favorável ao direito ao ambiente como um direito fundamental (direitos subjetivos pessoais ou patrimoniais), prefere tratar o ambiente não como um direito, mas como um dever fundamental de proteção:

Gostaríamos de acentuar que a nossa preferência pela figura do dever fundamental de protecção do ambiente decorre, em primeiro lugar, dos obstáculos técnicos revelados pela concepção do direito ao ambiente - indeterminação e indeterminalidade da medida de fruição individual de cada componente ambiental -, obstáculos esses ultrapassáveis pela via do dever fundamental. (GOMES, 2012, p. 101-102)

O dever fundamental configura um substrato autônomo, que não é necessariamente reflexo de um direito: o dever de votar representa um direito fundamental ao sufrágio universal, diferentemente do dever de defesa da pátria que, em vez de corresponder a um direito, significa restrição de liberdade de circulação e de exercício de profissão, por exemplo. Nessa mesma linha, o dever de proteção ao meio ambiente não 
corresponde a um direito ao meio ambiente, dada a indeterminabilidade de apropriação individual desse tipo de bem. Ao tratar como um dever fundamental, portanto, consegue-se não só caracterizá-lo como uma tarefa estatal, como vincular todos os cidadãos, dentro de uma lógica de solidariedade, a comportamentos concretizadores deste dever, na medida da diferença das suas situações específicas (GOMES, 2012).

A despeito dos argumentos contrários explanados, a doutrina majoritária ${ }^{6}$ à qual esta pesquisa se filia entende que o meio ambiente ecologicamente equilibrado deve ser tratado como um direito fundamental, tendo como base as prescrições dos artigos $1^{\circ}$, inciso III (dignidade da pessoa humana como fundamento da república), $5^{\circ}$, caput (direito à vida como um direito individual fundamental) e $60, \S 4^{\circ}$, inciso VI (direitos e garantias individuais como cláusula pétrea, isto é, que não pode ser modificada pelo constituinte atual), todos da Constituição da República Federativa do Brasil de 1988.

Sendo assim, vale dizer que o meio ambiente, classicamente considerado como um direito difuso, coletivo e inserido na $3^{a}$ geração de direitos, assumiu outra dimensão na contemporaneidade, caracterizandose como direito social e pilar do Estado Ambiental.

Em seu magistério, José Afonso da Silva (2011, p. 287) considera que os direitos sociais:

São, portanto, direitos que se ligam ao direito de igualdade. Valem como pressupostos do gozo dos direitos individuais na medida em que criam condições materiais mais propícias ao aferimento da igualdade real, o que, por sua vez, proporciona condição mais compatível com o exercício efetivo da liberdade.

Nesse sentido, Silva (2011, p. 317) enfeixa seu posicionamento acerca do direito ao meio ambiente como um direito fundamental social: "É um campo que integra, na sua complexidade, a disciplina urbanística,

$6 \quad$ CF. Hartman, 2010. 
mas se revela como social, na medida em que sua concreção importa em prestação do Poder Público."

O professor alemão Robert Alexy levanta duas teses favoráveis ao direito fundamental como um direito social, ambas fincadas na liberdade, sendo a primeira "a liberdade jurídica, isto é, a permissão jurídica de fazer ou deixar de fazer algo, não tem valor sem uma liberdade fática (real), isto é, a possibilidade fática de escolher entre as alternativas permitidas" (STEINS apud ALEXY, 2011, p. 503). Depreende-se dessa primeira tese que a liberdade jurídica não basta; é necessária a concretização dessa liberdade no mundo real, no cotidiano (liberdade fática).

Com relação à segunda tese, Robert Alexy (2011) afirma que “ [...] sob as condições da moderna sociedade industrial, a liberdade fática de um grande número de titulares de direitos fundamentais não encontra seu substrato material em um 'espaço vital por eles controlados', ela depende sobretudo de atividades estatais" (SCHWABE apud ALEXY, 2011, p. 504). Sendo assim, pode-se considerar que, além de ser necessária a materialização da liberdade no mundo real, é preciso que as escolhas estejam no universo de controle do indivíduo, não bastando escolher entre duas ou mais alternativas para as quais não se tenha ingerência. Em outras palavras, a escolha somente se configura como liberdade fática dentro de um leque de alternativas permitidas, e não sob a imposição de opções pré-estabelecidas. Se assim o fosse, não haveria falar em direito fundamental social. Enfeixa Robert Alexy (2011, p, 505), manifestando-se:

Mas essas teses não podem ser mais que apenas um ponto de partida de um argumento a favor dos direitos fundamentais sociais. Isso é facilmente perceptível a partir da constatação de que, mesmo sem aceitar a existência dos direitos fundamentais sociais, seria não apenas possível aceitar ambas as teses como, também, conceber a criação de uma liberdade fática como algo desejado na Constituição.

Dessa forma, a liberdade de escolha no mundo real deve estar dentro do espaço de controle de quem escolhe, não havendo liberdade real e, portanto, ofensa à liberdade jurídica quando as escolhas estão 
sob amarras e domínios estruturados num modelo de sociedade capitalista, tal como o que ocorre em relação ao meio ambiente. De que liberdade se trata se a satisfação de desejo de habitar próximo a áreas verdes, por exemplo, for uma condição exclusiva para alguns? Ou seja, as alternativas ofertadas a partir de referido modelo não são propriamente livres. São imposições travestidas de alternativas, porquanto excludentes, expropriadoras e segregadoras, sendo necessária a atuação estatal para que tais alternativas sejam de fato livres ou, no mínimo, para que o Poder Público atue como mitigador de possíveis distorções.

Portanto, dentro de um contexto expropriatório moldado pelo sistema capitalista, os objetivos e as atividades estatais é que conduzem à liberdade fática, que por sua vez materializa a liberdade jurídica, que, por seu turno, são os pilares para os que defendem a possibilidade de admitir direito fundamental como social. E se os direitos sociais são pressupostos para gozo dos direitos individuais (SILVA, 2011), significa que o Poder Público é o responsável, em última instância, por operar condições para que o direito fundamental individual à vida, por exemplo, seja respeitado. Aliás, acerca dos direitos fundamentais individuais, Moraes (2002, p. 63) leciona: "O direito à vida é o mais fundamental de todos os direitos, já que se constitui em pré-requisito à existência e exercício de todos os demais direitos." Para José Afonso da Silva (2004, p. 58),

Encontramo-nos, assim, como nota Santiago Anglada Gotor, diante de uma nova projeção do direito à vida, pois neste há de incluir-se a manutenção daquelas condições ambientais que são suporte da própria vida, e o ordenamento jurídico, a que compete tutelar o interesse público, há que dar resposta coerente e eficaz a essa nova necessidade social.

Depreende-se do exposto, então, que o direito ao meio ambiente ecologicamente equilibrado é uma extensão do direito à vida, razão pela qual é um direito fundamental. E é social porque necessita de atividades do Poder Público como instrumento de concretização de gozo do direito fundamental à vida digna. 
Para Milaré (2009, p. 819), o meio ambiente ecologicamente equilibrado "é, sem dúvida, o princípio transcendental de todo o ordenamento jurídico ambiental, ostentando o status de verdadeira cláusula pétrea". E não o é somente porque é base da própria existência humana - água e alimento -, mas porque todos têm direito a uma vida digna e de qualidade. "É que a tutela da qualidade do meio ambiente é instrumental no sentido de que, através dela, o que se protege é um valor maior: a qualidade da vida." (SILVA, 2004, p. 70).

Em síntese, seja para a corrente minoritária que defende que o meio ambiente não deve ser tratado como um direito fundamental preferindo, inclusive, tratá-lo como um dever fundamental, como é o caso de Gomes (2012) -, seja para a corrente majoritária que entende que o meio ambiente ecologicamente equilibrado é um direito fundamental, ambas as posições convergem num ponto: é imprescindível a atuação estatal na instrumentalização da proteção e equilíbrio ecológico ambiental. Portanto, se o meio ambiente é formado pelos ecossistemas natural e humano, e pela própria relação entre eles, essa dinâmica tem de se processar de forma equilibrada, não desigual, sob pena de comprometer a existência e ou a qualidade de vida humana e, por consequência, afrontar um dos fundamentos da república brasileira, a dignidade humana.

\subsection{Princípio do acesso equitativo aos recursos naturais}

Segundo Machado (2003), para quemo acesso aos bens ambientais pode ser tanto visando o consumo quanto para a contemplação da paisagem, tal princípio guarda estreita relação com os aspectos ligados ao desenvolvimento sustentável. $\mathrm{O}$ artigo $4^{\circ}$, inciso I, da Lei $n^{\circ} 6.938 / 81$, cujo marco teórico é conservacionista (oposição ao protecionismo da natureza intocada), já o indicava quando defendia a compatibilização do desenvolvimento econômico-social com a preservação da qualidade do meio ambiente e do equilíbrio ecológico.

Milaré (2009) o trata como princípio da solidariedade intergeracional porque "[...] traduz os vínculos solidários entre as gerações presentes 
e com as futuras" (MILARÉ, 2009, p. 820, grifos do autor). Ou seja, é preciso não comprometer a satisfação das necessidades das gerações futuras, mas também há de se ressaltar que é essencial não se retrair o uso dos recursos naturais ao ponto de comprometer as gerações atuais. Explorando-os diretamente e de forma equilibrada ou acessando indiretamente o produto econômico dessa exploração, via distribuição de renda, as gerações atuais podem ver respeitado o princípio do acesso equitativo aos recursos naturais, porque "Os usuários só poderão usar os bens ambientais na proporção de suas necessidades presentes, e não futuras" (MACHADO, 2003, p. 51). Há de se buscar, portanto, o equilíbrio no usufruto dos recursos e serviços ambientais.

\subsection{Princípio do usuário-pagador}

Esse princípio é mencionado no artigo $4^{\circ}$, inciso VII, in fine, da Lei $n^{\circ} 6.938 / 81$, e tem alta relevância para esta pesquisa, uma vez que o referido dispositivo preceitua que caberá ao usuário a "contribuição pela utilização de recursos ambientais com fins econômicos" (BRASIL, 1981). Da mesma forma, a contribuição de melhoria é um tributo de base econômica que pode ser cobrado ao proprietário de imóveis, em contrapartida da valorização decorrente de obras públicas que, em última análise, sejam as responsáveis pelo acréscimo de valor em propriedades privadas. Para Machado (2003, p. 53), "o uso gratuito dos recursos naturais tem representado um enriquecimento ilegítimo do usuário, pois a comunidade que não usa do recurso ou que o utiliza em menor escala fica onerada".

Nesse sentido, e diferentemente do princípio do poluidorpagador, que, no mais das vezes, tem caráter sancionatório, o princípio do usuário-pagador acaba por nortear a socialização econômica dos benefícios ambientais, importante no valor da solidariedade incutido no Estado de Direito Ambiental, que será estudado mais adiante. Por ora, convém ressaltar que:

Funda-se este princípio no fato de os bens ambientais - particularmente os recursos naturais - constituírem 
patrimônio da coletividade, mesmo que, em alguns casos possa incidir sobre eles um justo título de propriedade privada. Sabemos, outrossim, que recursos essenciais, de natureza global - como a água, ar e o solo - não podem ser 'apropriados' a bel talante. (MILARÉ, 2009, p. 829)

Como os bens ambientais pertencem a todos, o usufruto deles não está na esfera de disponibilidade do particular, assim como não está o produto de sua exploração econômica, seja física, seja visual, a exemplo dos recursos paisagísticos. Dessa forma, o princípio do usuáriopagador tem estreita relação também com o art. 225, caput, da CF/88, na medida em que atua na dimensão socioeconômica da sustentabilidade e participa do processo de equilíbrio entre os ecossistemas natural e humano.

Portanto, os princípios elencados, previstos pela Lei $n^{\circ} 6.938 / 81$ (Política Nacional do Meio Ambiente), foram importantes para a construção dos princípios ambientais albergados pela Constituição da República Federativa do Brasil de 1988, que, ao estabelecer os fundamentos e objetivos da própria república, sinaliza eleger a nação brasileira como um Estado de Direito Ambiental. Por isso, na seção seguinte, será aprofundada a relação entre o Estado de Direito Ambiental e a Constituição Federal de 1988.

\section{O Estado de Direito Ambiental e a Constituição Federal do 1988}

Embora o termo "Estado Ambiental" tenha sido cunhado pelo austríaco Norbert Wimmer em 1976, foi o jurista alemão Michael Kloepfer, em 1989, o primeiro a dedicar-se aos elementos de um Estado Ambiental (HARTMANN, 2010). Também denominado de Estado Constitucional Ecológico (CANOTILHO, 2001), é um constructo teórico que orienta a ordem jurídica de uma nação para as questões ambientais, especialmente nos dias atuais quando se discute a problemática ambiental e a relação homem-natureza, diante da finitude dos recursos naturais, de um lado, 
e das necessidades das presentes e das futuras gerações, de outro, quanto à qualidade de vida e bem-estar social.

Vive-se, portanto, numa sociedade de risco, característica da fase seguinte ao período industrial clássico, que, para Leite (2007, p. 132), "é aquela que em função de seu contínuo crescimento econômico, pode sofrer a qualquer tempo as consequências de uma catástrofe ambiental". Mas mais do que isso: os riscos reforçam as desigualdades sociais, na medida em que "a história da distribuição de riscos mostra que estes se atêm, assim como as riquezas, ao esquema de classe - mas de modo inverso: as riquezas acumulam-se em cima, os riscos em baixo" (BECK, 2011).

Belchior (2011, p. 21), referindo-se ao Estado Constitucional Ecológico como Estado de Direito Ambiental ou simplesmente Estado Ambiental, defende que:

[...] urge a construção de um Estado de Direito Ambiental que venha a se adequar à crise ecológica e à sociedade de risco, possuindo princípios fundantes e estruturantes, contornos e metas para tentar minimizar os efeitos dos impactos negativos no meio ambiente. Não há dúvida de que, no entanto, a necessidade de construção de um Estado de Direito Ambiental implica mudanças profundas na estrutura da sociedade e na atividade estatal, como objetivo de apontar caminhos em resposta aos novos pilares de uma sociedade de risco.

O Estado Ambiental, a partir dos princípios que o estruturam, é a base norteadora para lidar com as consequências da problemática ambiental na qual a sociedade, sob risco, está inserida. Nesse sentido, o esforço para construir teoricamente esse tipo de Estado segundo uma ordem jurídica pátria será maior ou menor a depender dos dispositivos constantes da Constituição Federal de cada país e das legislações infraconstitucionais pertinentes, a partir dos quais se buscam mecanismos práticos de concretização de referido constructo teórico. 
Um desses mecanismos é a hermenêutica, que, na sua conceituação clássica, "é a teoria científica da arte de interpretar" (MAXIMILIANO, 2010, p. 2). Ela cuida da sistematização do processo de interpretação, que, na área jurídica, é a extração do sentido e do alcance das palavras e expressões inerentes ao Direito.

Na mesma linha, posiciona-se a hermenêutica jurídica ambiental, que, no tocante aos aspectos ligados à natureza e ao homem, tem como ponto de referência os objetivos e finalidades da Carta Política.

As normas precisam ser interpretadas de forma a concretizar o Estado de Direito Ambiental. Por mais que a Constituição e até mesmo as normas infraconstitucionais permaneçam em muitos pontos inalteradas, o intérprete deve perceber o movimento dialético do Direito, formado por raciocínios jurídicos não apenas dedutivos, mas também indutivos, o que justifica a importância de uma hermenêutica jurídica ambiental. (BELCHIOR, 2011, p. 21)

Desse modo, se as leis (constitucionais ou não) são feitas para atender aos reclamos sociais e, portanto, são genéricas e abstratas porque se torna impossível prever todos os casos merecedores de normatividade, cabe à aplicação do Direito harmonizar os interesses socioambientais, através de processos de interpretação, tal como salientou Belchior (2011).

Para Barroso (2009), bebendo na fonte da sistematização clássica e privatista de Savigny, os métodos ou elementos clássicos de interpretação são: gramatical (textual, literal, momento inicial da interpretação); histórico (busca de sentido através de precedentes legislativos); sistemático (entender as partes para compreender o todo e vice-versa, a partir de uma ideia de que o ordenamento jurídico é uno); e teleológico (o fim da norma, o valor ou bem jurídico visado pelo ordenamento jurídico).

Segundo Maximiliano (2010), tais processos podem ser: gramatical (apego à literalidade vocabular); lógico (encadeamento lógico-dedutivo entre os dispositivos da lei e o caso concreto); histórico (busca a origem 
da norma, fazendo levantamento de ideias e interesses dominantes ao tempo de sua elaboração); sistêmico (partes de uma ou várias leis, formando um todo harmônico incidente sobre o mesmo objeto de análise ou fato social); teleológico (fim colimado da lei); e sociológico, sob um viés moderador, "tira todas as deduções exigidas pelo meio social, porém compatíveis com a letra da lei; evita os exageros dos revolucionários, mas também se não conforma com a imobilidade emperrada, produto lógico da dogmática" (MAXIMILIANO, 2010, p. 41).

Em que pese a importância dos métodos clássicos, há que se ter em vista que, a partir da Constituição de 1988, ato não apenas instituidor de um novo Estado brasileiro, sobretudo portal estruturante de uma nova sociedade, a chamada "nova hermenêutica"7, conjunto de novos métodos de interpretação fundados na avaliação axiológiconormativa expressa na Carta Maior, passou a preponderar no esforço de interpretação constitucional.

Importante a referência à Teoria da Norma de Friedrich Müller. Para o jurista alemão, a norma não se confunde com texto de norma. Para haver norma, tem de haver a confluência entre os dados linguísticos (texto de norma) e os dados reais (caso concreto). A norma jurídica surge no processo de concretização, decorrendo daí que não pode ser simplesmente aplicada, porque não está pronta nem substancialmente acabada. Sob o ponto de vista teórico, trata-se de uma impossibilidade lógica (GOMES, 2009).

A teoria e a metódica estruturantes da norma propostas por Muller rejeitam a "interpretação aplicadora" do direito em favor da concretização, uma vez que concretizar transcende o ato de interpretar, representando a própria produção da norma. Concretizar significa "produzir diante da provocação pelo caso de conflito social, que exige uma solução jurídica, a norma jurídica defensável para esse caso no quadro de uma democracia e de um Estado de Direito" (MÜLLER apud GOMES, 2009).

Cf. Alexy (2011); Bonavides (1999); Barroso (2009); Jacintho (2009). 
Não há, pois, subsunção do fato à norma, posto que esta exsurge a partir do resultado do processo de concretização: ser e dever-ser, texto de norma e realidade, sem ordem hierárquica e numa inter-relação entre os dados linguísticos e os dados reais. Por outras palavras: a realidade faz parte da estrutura da norma.

A própria construção teórica que redundou na edificação de um Estado Ambiental se deu levando em conta a realidade social ambiental e a partir da ponderação de bens e valores, que se contrapõem constantemente no texto constitucional, cabendo ao intérprete aferir quais dos bens/valores/interesses devem preponderar naquela situação concreta, de forma a garantir a realização dos propósitos constitucionais por meio dos quais são, no mais das vezes, descontadas as distorções do sistema político, as opções da sociedade brasileira.

Em todo caso, além da abordagem inovadora trazida pelos métodos da Nova Hermenêutica no esforço interpretativo, a eles se somam os métodos tradicionais, a fim de melhor escolher os valores socialmente consagrados e transformados em normas de Direito.

O esforço hermenêutico jurídico ambiental, portanto, conta com a colaboração norteadora dos princípios constitucionais e dos fundamentos e objetivos da república, constantes da própria Carta Política, como alhures explanado. O texto constitucional, de início, elenca a cidadania e a dignidade da pessoa humana como dois de seus fundamentos (art. $1^{\circ}$, incisos II e II) ${ }^{8}$, estabelece a erradicação da pobreza e a marginalização e redução das desigualdades sociais (art. $3^{\circ}$, incisos I), e preceitua a construção de uma sociedade livre, justa e solidária (art. $3^{\circ}$, inciso III) como alguns dos objetivos fundamentais da res publica.

Todos esses objetivos funcionam como norteadores da atividade interpretativa e transformadora do Direito, especialmente quando

"Portanto, qualquer que seja a discussão sobre o meio ambiente, ela deve passar pelo filtro constitucional do art. $1^{\circ}$ e estar pautada sempre nos princípios ali insculpidos." (SALGE JÚNIOR, 2003, p. 89) 
se pretende concretizar direitos fundamentais. Há, no entanto, uma opção entre os doutrinadores do Direito em privilegiar o princípio da dignidade humana, como princípio central na concretização de direitos fundamentais, a exemplo do que faz Jussara Maria Moreno Jacintho (2009).

A ordem inaugurada em 1988 é composta por vários sistemas, os quais buscam coesão e harmonia por meio da atividade interpretadora. Essa atividade, contudo, há que ser presidida por uma lógica maior, que conduza inevitavelmente ao respeito aos direitos fundamentais assim como à ordem constituída [...] Conforme já explicitamos, esse papel é desempenhado pela concepção da dignidade humana, norma constitucional principiológica, a capitanear a interpretação constitucional. (JACINTHO, 2009. p. 35)

Além da dignidade humana, os demais fundamentos e objetivos prescritos na Constituição são, segundo Belchior (2011): a solidariedade como marco jurídico-constitucional do Estado de Direito Ambiental, e a sustentabilidade como marco axiológico captado de forma indutiva da crise ambiental.

A solidariedade ${ }^{9}$ está manifesta porque, embora estejam atentas às necessidades presentes, as gerações hodiernas também se comprometem a usufruir dos recursos naturais sem amputar a satisfação das necessidades das gerações futuras. Já a sustentabilidade está presente porque, calcada nas dimensões ambiental, econômica e social, é instrumentalizada pelo desenvolvimento sustentável, a partir do equilíbrio entre o crescimento econômico e a utilização racional dos recursos naturais, de modo a observar a qualidade de vida e não comprometer a própria sobrevivência humana. Nesse sentido, Silva (2004) entende que o desenvolvimento sustentável:

9 "Vê-se, portanto, que o emergente Estado Ambiental está baseado em experiências pluricausuais, devendo-se implementar, em sua complexidade, o promissor princípio da solidariedade econômica social, visando ao desenvolvimento sustentável, no qual a via para o bem-estar social ambiental das futuras gerações seja alicerçada pela igualdade entre os homens e o justo uso do patrimônio natural." (BANUNAS, 2003, p. 32) 
Requer, como seu requisito indispensável, um crescimento econômico que envolva equitativa distribuição dos resultados do processo produtivo e a erradicação da pobreza, de forma a reduzir as disparidades nos padrões de vida e melhor atendimento da maioria da população. (SILVA, 2004, p. 27, grifos do autor)

Belchior (2011) sintetiza bem o que é o Estado de Direito Ambiental (ver Figura 2.1): uma balança hipotética cuja base é a dimensão "AMBIENTAL, que atua no equilíbrio entre o lado "DEMOCRÁTICO" e o lado do "DIREITO". Essa analogia parte do raciocínio de que a "dialética promove a harmonia da balança, interagindo com todos os princípios e os valores do novo Estado de forma sistêmica e holística" (BELCHIOR, 2011, p. 127).

Figura 2.1 - Balança hipotética do Estado de Direito Ambiental

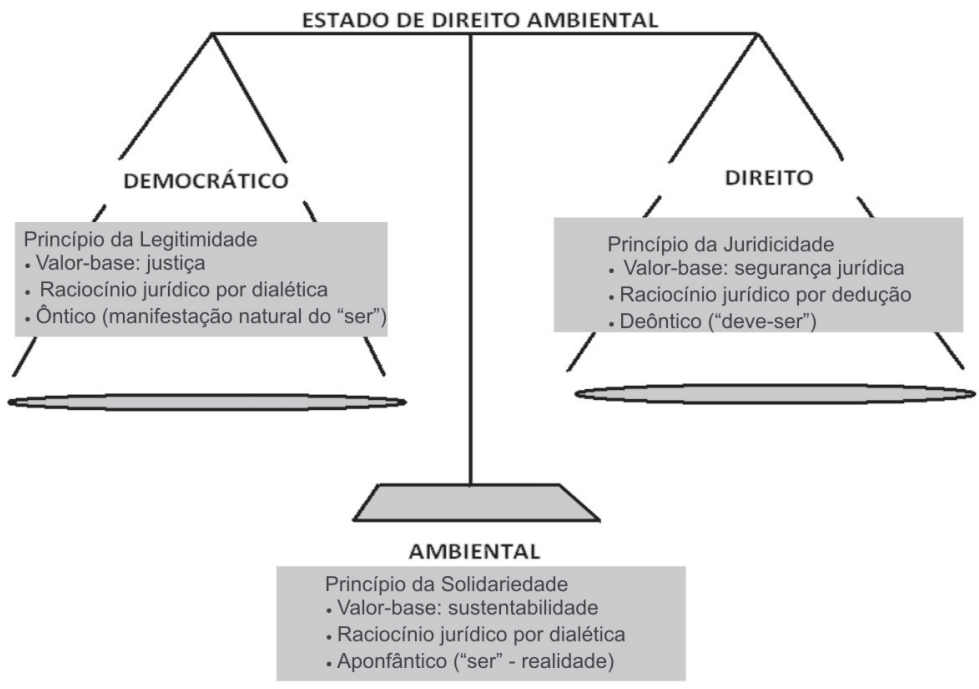

Fonte: Belchior (2011, p. 127) 
Portanto, o constructo teórico a que se refere a balança hipotética tem, em sua base, a dimensão ambiental, cujo valor é a sustentabilidade e o princípio é a solidariedade. Assim, a partir das concepções delineadas sobre valor e princípio, pode-se considerar que o melhor (valor) para a sociedade de risco dos dias atuais é a sustentabilidade, e que o caminho devido (princípio) é a solidariedade.

O Estado de Direito Ambiental, base da democracia e do direito, é construído a partir de processos de interpretação (gramatical, histórico, lógico, sistemático e teleológico) em concomitância, de modo a extrair do Diploma Maior o sentido, o alcance e o marco axiológico promulgado pela Carta Política. Cumpre ressaltar que tais processos vão além do método clássico, tal como o encontrado na nova hermenêutica concretizadora.

Esse processo de sistematização interpretativa defendido pela nova hermenêutica jurídica ambiental permite considerar a nação brasileira como um Estado de Direito Ambiental, para cuja concretização, além da própria hermenêutica mencionada, faz uso também de instrumentos econômico-tributários, a exemplo do tributo como um instrumento e do usuário-pagador como princípio que busca assegurar o equilíbrio entre todos que têm direito ao uso dos benefícios trazidos pelo meio ambiente.

\section{Estado de Direito Ambiental e a tributação}

Consoante demonstrado, uma das interpretações possíveis do texto constitucional adota a perspectiva do meio ambiente como o norteador da ordem jurídica brasileira, traduzida em um Estado de Direito Ambiental, que, a partir da base teórico-legislativa do Estado de Direito Democrático, escolhe como valor supremo o uso sustentável e a preservação ambiental para as presentes e futuras gerações.

Tributo é o meio principal de que o Estado - "ordem jurídica soberana que tem por fim o bem comum de um povo situado num determinado território" (DALLARI, 2012, p. 122) - dispõe para financiar sua atividade. $\mathrm{O}$ artigo $3^{\circ}$ do Código Tributário Nacional (Lei $n^{\circ} 5.172 / 66$ ) 
define o tributo como "toda prestação pecuniária compulsória, em moeda ou cujo valor nela se possa exprimir, que não constitua sanção de ato ilícito, instituída em lei e cobrada mediante atividade administrativa plenamente vinculada" (BRASIL, 1966). Em outras palavras, é o pagamento obrigatório (não voluntário), geralmente em dinheiro, que não tenha caráter sancionatório, cuja obrigação e procedimentos de cobrança (lançamento, arrecadação e fiscalização) decorram de lei.

Tributação e solidariedade andam em compasso. "O princípio da solidariedade constitui fundamento para a atuação do Estado, que há de promover a solidariedade social. E para tanto, pode mesmo utilizar a tributação como mecanismo de redistribuição de renda." (MACHADO, 2008, p. 44-45). Essa solidariedade não é aquela fraterna e volitiva, mas a oriunda de um dever jurídico, em que o Estado precisa atuar para harmonizar as relações sociais que invariavelmente são caracterizadas por desigualdades, mormente quando o modelo de sociedade é pautado no padrão capitalista de desenvolvimento econômico.

Nesse sentido, impõe-se ao Estado minimizar essas diferenças por meio da sua função reguladora da economia, preconizada pelo artigo 170 da Constituição de $1988^{10}$, cuja defesa do meio ambiente, inclusive mediante tratamento diferenciado, é um dos princípios da ordem econômica, conforme o impacto ambiental dos produtos e serviços e de seus processos de elaboração e prestação. A inércia estatal, nesse contexto, pode significar um incentivo à referida desigualdade social

10 "Art. 170. A ordem econômica, fundada na valorização do trabalho humano e na livre iniciativa, tem por fim assegurar a todos existência digna, conforme os ditames da justiça social, observados os seguintes princípios: I - soberania nacional; II - propriedade privada; III - função social da propriedade; IV - livre concorrência; V - defesa do consumidor; VI - defesa do meio ambiente; $\mathrm{VI}$ - defesa do meio ambiente, inclusive mediante tratamento diferenciado conforme o impacto ambiental dos produtos e serviços e de seus processos de elaboração e prestação; (Redação dada pela Emenda Constitucional $n^{\circ} 42$, de 19.12.2003). VII - redução das desigualdades regionais e sociais; VIII - busca do pleno emprego; IX - tratamento favorecido para as empresas brasileiras de capital nacional de pequeno porte. IX - tratamento favorecido para as empresas de pequeno porte constituídas sob as leis brasileiras e que tenham sua sede e administração no País. (Redação dada pela Emenda Constitucional nº 6, de 1995) [...] Parágrafo único. É assegurado a todos o livre exercício de qualquer atividade econômica, independentemente de autorização de órgãos públicos, salvo nos casos previstos em lei." (BRASIL, 1988) 
e uma falha no âmbito de políticas públicas, conforme destaca May (2001, p. 57):

A falha governamental é evidente na fraqueza de políticas que visam melhorar as condições dos segmentos de baixa renda. Quando somados à ineficiência burocrática, à busca da arrecadação [desmedida e confiscatória] e à corrupção, essas falhas fortalecem o ceticismo em relação às instituições públicas, duvidando que elas possam ser capazes de administrar os recursos naturais com sabedoria ou alocá-los equitativamente.

É dever do Estado, em razão de suas deficiências, buscar um mecanismo de melhoria social e de distribuição equitativa dos recursos, inclusive os provindos da exploração econômica, em uma perspectiva de política de Estado e de governo, ambos direcionados à sustentabilidade.

Isto implica a necessidade quer de utilização cuidadosa da base biofísica, ambiental da economia, quer uma reorientação na maneira como os recursos da natureza são empregados e os correspondentes benefícios, compartilhados [...] Encarecendo a geração de lixo, via um tributo ou outra forma de desincentivo, uma receita pode ser simultaneamente obtida para fins de promoção social ou proteção ecológica. (CAVALVANTI, 1999, p. 30-33)

Segundo Modé (2004, p. 72), "os tributos ambientais buscam prevenção dessas desigualdades, sejam elas verificáveis no âmbito exclusivamente da economia ou, num sentido amplo, da realização da justiça”. Na mesma linha, filia-se Carraza (2011, p. 754).

Em suma, da concepção do tributo como meio de obtenção de recursos avançou-se para a ideia de que pode e deve ser utilizado para favorecer a realização dos mais elevados objetivos sociais, econômicos e políticos. Converteuse, pois, num instrumento privilegiado de intervenção estatal, em ordem a possibilitar, por exemplo, uma melhor distribuição da renda do País. 
Essa distribuição de renda por conduto de tributo opera a partir do princípio da igualdade ou isonomia ${ }^{11}$, tendendo à observância da capacidade contributiva ${ }^{12}$, ou seja, quem tem maior potencialidade econômica contribui mais para a atividade financeira estatal. Vale lembrar que tal distribuição é instrumentalizada também pelo princípio da proporcionalidade, isto é, quem proporcionalmente se beneficia mais contribui mais, numa relação jurídica de solidariedade social.

\section{Redistribuição de renda e a contribuição de melhoria}

O jurista Hugo de Brito Machado (2008), ao se referir à finalidade redistributiva da contribuição de melhoria, elabora o seguinte conceito: "Podemos dizer que a contribuição de melhoria é o tributo destinado a evitar uma injusta repartição dos benefícios decorrentes de obras públicas." (MACHADO, 2008, p. 435). Mas que é justiça?

Segundo Pessoa (2007), John Rawls percebe que uma concepção de justiça não pode anular os dons naturais nem as contingências ou desigualdades sociais que vão incidir nas estruturas política, econômica e, em geral, em todas as dimensões da vida. Nesse sentido, a aplicabilidade das propostas apresentadas na presente pesquisa, na medida em que defende uma redistribuição mais equânime dos benefícios econômicos oriundos de um bem público ambiental (Parque Augusto Franco), aproxima-se, guardadas as proporções pertinentes,

11 Para Rodrigues (2002, p. 87), "a desigualdade social, assim como a falta da capacidade de contribuir, justifica tratamento desigual para favorecer os desfavorecidos, em obediência ao princípio da isonomia".

12 Embora a prescrição constitucional atrele o princípio da capacidade contributiva somente a impostos (art. $145, \S 1^{\circ}, \mathrm{CF} / 88$ ), o STF relativiza este entendimento ao manifestar-se pela aplicabilidade de tal princípio à Taxa de Fiscalização da CVM (RE 216.259 - AgR, rel. Min. Celso de Mello, 19-05-2000) e à taxa judiciária progressiva (ADlin n. 948/GO, Pleno, rel. Min. Francisco Rezek, j. 09-11-1995). Para Sabagg (2013, p. 164), "[...] o princípio da capacidade contributiva deve, evidentemente, ser observado, também, por outros tributos, obedecendo, todavia, às peculiaridades de cada espécie tributária". Segundo Araújo et. al. (2003, p. 26), "Por este princípio, os impostos devem ser progressivos, ou seja, devem estar de acordo com a capacidade econômica do contribuinte. Nada impede também que as taxas e as contribuições de melhoria tenham essa progressividade. Para estes últimos, contudo, a progressão fica a critério de lei ordinária.". 
da concepção de justiça como equidade, teorizada por John Rawls (1997), para quem as desigualdades econômicas e sociais somente serão toleradas (princípio da distribuição) se beneficiarem os menos favorecidos (princípio da diferença) ou estiverem vinculadas a cargos e posições de acesso universal (princípio das oportunidades equitativas).

Já de acordo com Torres (1995, p. 272):

O outro princípio vinculado à ideia de justiça, que tem implicações com o problema da igualdade, é o do custo/ benefício. Informa os tributos contraprestacionais - taxa e contribuição de melhoria. Significa que a incidência deve equilibrar o custo que o Estado teve para fornecer serviços ou obras com o benefício auferido pelo contribuinte. A desigualdade consistirá no tratamento discriminatório, por desproporcionado, contra pessoas ou grupos, mas não no desequilíbrio que venha a ocorrer na equação financeira do custo/benefício.

A injusta repartição referida, porquanto desequilibrada a equação financeira custo/benefício, pode ser evidenciada na dinâmica existente na região de entorno do Parque Augusto Franco: por razões mercadológicas e de poder aquisitivo, proprietários de unidades imobiliárias localizadas de frente ou nas proximidades para referido parque desfrutam de privilégios ofertados pelos serviços ecossistêmicos oriundos desse bem público ambiental, não extensíveis a outras camadas sociais da população. Essas outras classes sociais também participam no custeio da manutenção do parque, através dos impostos (ISSQN, IPTU, ITBI), mas não usufruem, na mesma proporção, dos benefícios gerados pelo bem que ajudam a manter. Essa é a injustiça.

Geraldo Ataliba (1996), ao alegar que se o proprietário em nada concorreu para a obra (que gera valorização) não é justo que se aproprie desse específico benefício, elege várias razões para efetivação do instrumento contribuição de melhoria: a) razões financeiras, pela necessidade de recursos para enfrentar a própria obra ou outras; b) razões econômicas, para desestimular a especulação imobiliária, devido ao não uso e retenção de terrenos nos arredores das cidades, 
aguardando valorização, com consequente desvio de capitais de empreendimentos produtivos e criação de favelas; c) razões políticas, devolvendo à coletividade os benefícios e frutos de sua ação, de modo a não premiar a improdutividade dos que adquirem imóveis por preços baixos aguardando valorização por efeito do progresso, expansão urbana e realização de obras públicas; d) razões de equidade, para que as obras de utilidade geral sejam custeadas por todos, as de utilidade restrita sejam por aqueles que dela extraiam proveito e as que se relacionam com os requisitos sejam custeadas proporcionalmente entre a comunidade e os beneficiários; e) razões éticas, para banir o enriquecimento sem causa de alguns, à custa de todos (ATALIBA, 1996).

Como a contribuição de melhoria é um tributo vinculado à obra pública e as benesses decorrem dessa mesma obra pública, justo seria se os mais beneficiados contribuíssem com um valor maior para construção ou manutenção de referido bem público. Como atualmente os gastos são custeados pelo produto da arrecadação dos impostos não vinculados, com a contribuição de melhoria, será possível não comprometer o montante de receita aplicado na manutenção de parques públicos e destiná-lo a outros tipos de políticas públicas, tais como: projetos de educação ambiental, arborização de praças, recuperação de áreas ambientalmente degradadas, ou mesmo concedendo isenções de IPTU, por exemplo.

No caso de isenções, ocorre uma espécie de redistribuição de renda que se configura não só pelo modelo clássico de destinação direta de dinheiro público a classes sociais de menor poder aquisitivo, mas também por conduto de medidas que livram determinados contribuintes do pagamento de tributo. Em outras palavras, o "deixar de pagar" também é redistribuição de renda, a partir da seguinte dinâmica: o dinheiro sai de quem tem mais e vai para o Estado, via contribuição de melhoria; o Estado, por sua vez, libera do pagamento de impostos aqueles que, mesmo com um poder aquisitivo menor, pagavam indiretamente pela construção ou manutenção de parques. Liberados desses pagamentos, essas pessoas poderão aplicar sua renda "extra" na satisfação de suas 
necessidades cotidianas, resultando, na prática e de forma indireta, na redistribuição de renda.

$\mathrm{Na}$ prática, seria transferir recursos de quem se beneficia dos serviços ambientais de parques públicos e aplicá-los em áreas ligadas ao meio ambiente, bem de uso comum de toda coletividade e direito fundamental à sadia qualidade de vida. Tal medida não encontra óbice jurídico, tendo em vista que a destinação do produto da arrecadação não desqualifica a natureza jurídica da contribuição de melhoria ${ }^{13}$.

Assim, se se permite mitigar o processo de desigualdade social a partir da distribuição de renda, a tributação ambiental é um instrumento de concretização do Estado Ambiental, porque atende ao marco jurídico-constitucional da solidariedade; e observa também a axiologia da sustentabilidade, na medida em que busca a mitigação das distorções sociais, envolvendo o equilíbrio e a compatibilização entre o desenvolvimento econômico, ambiental e social, nas gerações presentes e nas futuras. Como a contribuição de melhoria é tributo, logo, é compatível com o Estado de Direito Ambiental.

\section{Contribuição de melhoria: uma nova abordagem}

O Parque Augusto Franco, em Aracaju-SE - proposição de referência para análise -, é um bem público decorrente de uma atividade estatal para sua construção. Atualmente, os gastos com sua manutenção são oriundos de impostos como ISSQN, IPTU e ITBI, cujos fatos geradores não estão vinculados a uma atividade estatal específica. Nesse sentido, indaga-se: é possível a incidência da contribuição de melhoria para custear os gastos com manutenção do parque? Para responder a essa pergunta, será necessário saber o que é "obra pública”, para fins de incidência da contribuição de melhoria. Assim,

\footnotetext{
13 "Art. $4^{\circ} \mathrm{A}$ natureza jurídica específica do tributo é determinada pelo fato gerador da respectiva obrigação, sendo irrelevantes para qualificá-la: I - omissis...; II - a destinação legal do produto da sua arrecadação." (BRASIL, 1966).
} 
imperiosa é a invocação do artigo 145 da Constituição Federal ${ }^{14}$, que prevê a existência de referido tributo no mundo jurídico.

O artigo 81 do Código Tributário Nacional (Lei n 5.172/66), que complementa a Constituição, nesse ponto, preceitua:

Art. 81. A contribuição de melhoria cobrada pela União, pelos Estados, pelo Distrito Federal ou pelos Municípios, no âmbito de suas respectivas atribuições, é instituída para fazer face ao custo de obras públicas de que decorra valorização imobiliária, tendo como limite total a despesa realizada e como limite individual o acréscimo de valor que da obra resultar para cada imóvel beneficiado. (BRASIL, 1966)

Carvalho (2011, p. 74) diz que "do crescimento valorativo que o imóvel experimente, em razão da obra realizada pelo Estado, quer o direito positivo brasileiro que seu proprietário colabore com o Erário, pagando a chamada contribuição de melhoria". Sendo assim, a contribuição de melhoria é um tributo atrelado a uma atuação estatal que é a realização de obra pública. Porém, não é suficiente a realização de obra pública para ocorrência do fato gerador desse tributo. Pode-se dizer que "a contribuição de melhoria é tributo que depende de fato complexo para nascer" (RODRIGUES, 2002, p. 117). Hão de existir, pois, a obra pública e a valorização dela decorrente. Obra sem valorização, ou maisvalia imobiliária não decorrente especificamente da obra, não enseja a contribuição de melhoria. A aferição da valorização imobiliária cabe a outras ciências, a exemplo da estatística ou econometria. Entretanto, o sentido e alcance da expressão "obras públicas" é tarefa do Direito, que, a fim de interpretar com maior completude possível, há de estar atento ao contexto cotidiano pertinente.

14 "Art. 145. A União, os Estados, o Distrito Federal e os Municípios poderão instituir os seguintes tributos:

I - impostos; II - taxas, em razão do exercício do poder de polícia ou pela utilização, efetiva ou potencial, de serviços públicos específicos e divisíveis, prestados ao contribuinte ou postos a sua disposição; III - contribuição de melhoria, decorrente de obras públicas." (BRASIL, 1988, grifos nossos). 
A doutrina jurídica sobre a matéria considera que obras públicas, para fins de incidência da contribuição de melhoria, referemse à construção de estradas, pontes, viadutos, parques etc., isto é, a expressão restringe-se a aspectos conceituais ligados apenas à construção física, da qual decorra a valorização imobiliária. Entretanto, esse conceito não guarda relação com o texto constitucional, ou melhor, relaciona-se parcialmente com a Carta Política.

De fato, há de existir, de antemão, uma obra pública. No entanto, a Constituição Federal não determina que o fato gerador da contribuição de melhoria seja a valorização decorrente da "construção de obra pública". Prescreve que a valorização seja decorrente de "obra pública", donde se extrai que ela pode ser tanto em relação aos aspectos construtivos quanto aos aspectos extensíveis à obra pública, mas vinculados ao bem público que dela resultou. Esse é o caso dos serviços ambientais ínsitos ao bem público Parque Augusto Franco, que é resultado de uma obra estatal.

O valor que esse bem público tem para a coletividade compõese de um conjunto de elementos que o caracterizam. O aspecto físicoconstrutivo, os equipamentos públicos, a localização, o ar puro ofertado, a beleza cênica singular e até a restrição legal para erguimento de edifícios, todos eles são componentes ambientais, sem os quais resta desconfigurado o referido bem público. Não é o caráter estanque relacionado à construção física de per se que o faz de relevante interesse social, mas a permanência dessa condição integradora que o torna atraente aos objetivos do mercado. Noutro dizer, é o complexo artificial, natural e até cultural que, dado o cuidado e o zelo, torna a manutenção tão ou mais importante do que a mera construção ${ }^{15}$. Nesse

\footnotetext{
15 "A partir de 1988, as construções e edificações não são mais o monte central da gestão das cidades, e sim as interrelações (sic) entre as pessoas, vidas, em um cotidiano para qual a beleza e a conservação da paisagem são tão valorizados quanto sua utilidade [...] De tal forma que a mudança na concepção de Urbano fez atrelar a ideia de função estética à funcionalidade, à economia, à paisagem e ao concreto dos espaços urbanos." (SOUZA, 2006, p. 6)
} 
contexto, o que vai importar, pois, é se, por exemplo, da manutenção da obra pública decorre a valorização quantificável do imóvel beneficiado.

Segundo Carraza (2011, p. 592, grifo nosso), “obra pública, na magistral lição de Celso Antônio Bandeira de Mello, é a construção, edificação, reparação, ampliação ou manutenção de um bem imóvel, pertencente ou incorporado ao patrimônio público". E continua o autor, admitindo o caráter amplo do conceito de obras públicas para fins de incidência da contribuição de melhoria:

Indiscutível que abrem espaço a esta tributação as obras públicas do primeiro tipo, isto é, que causam proveito público imediato e a utilidade que proporcionam é desfrutada diretamente, e não por intermédio de serviços públicos [...] Mas também as obras públicas do segundo tipo entremostram-se aptas a fazer nascer a contribuição de melhoria. Ao contrário do que afirmamos em edição anterior, hoje estamos convencidos de que mesmo as obras públicas interligadas a serviços - desde que comprovadamente valorizem os imóveis a elas adjacentes - ensejam tributação via de contribuição de melhoria. De fato, se a Constituição não distinguiu, porquanto se limitou a autorizar as pessoas políticas a instituir "contribuição de melhoria, decorrente de obras públicas', não cabe ao intérprete fazer distinções. (CARRAZA, 2011, p. 593).

Carraza (2011), embora não aprofunde a análise, indica o caráter amplo que a expressão "obra pública" foi adotada pela Constituição Federal, na medida em que admite que serviços inerentes à própria obra pública possam dar azo ao contributo supramencionado.

Assim, por meio de métodos matemático-estatísticos, havendo a comprovação de que os serviços ecossistêmicos integrantes de um bem público que decorrem de uma obra pública mantida pelo Poder Público influenciam o valor de unidades imobiliárias ${ }^{16}$, e considerando exatamente a manutenção de tal patrimônio nessa condição de importante valor ao

16 Cf. Barbosa (2014). 
meio ambiente, é possível a incidência da contribuição de melhoria na espécie, a fim de custear tal manutenção.

Sob outra ótica, embora reforçando a linha de raciocínio traçada, os efeitos da urbanização, e, portanto, da ocupação e uso do solo, podem desencadear um processo de valorização dos imóveis localizados no entorno de parques, pois, à medida que a cidade vai crescendo, a carência de terrenos para construir vai aumentando, ocasionando a disputa por cada $\mathrm{m}^{2}$ disponível, crescendo a demanda e, com ela, os preços desse tipo de imóvel.

Ademais, o $\mathrm{m}^{2}$ localizado em frente ou nas proximidades de um patrimônio ambiental - que, por essa condição, impede a construção de prédios e, portanto, de edificações que atrapalhem a circulação do ar ou obstaculize a visão e o desfrute da beleza cênica do parque, por exemplo ${ }^{17}$ - tanto mais raro se torna quanto mais valorizado fica, pois o mercado traduz essas circunstâncias como sendo uma variável importante na valorização de imóveis urbanos.

Ou seja, a conservação das condições daquela região contemplada por parques públicos significa a própria valorização dos imóveis localizados em seu entrono, uma vez que a migração da urbanização para outras áreas provoca um efeito de "exclusividade" ou "singularidade" da região onde se estabelecem esses bens públicos de reconhecida importância aos ecossistemas humano e natural da localidade.

Nesse sentido, os serviços de manutenção do parque estão inseridos no conceito de "obras públicas" para fins de incidência da contribuição de melhoria, pois significam a conservação das próprias condições mercadológicas da região, o que, desde que constatada a valorização imobiliária em razão disso (em momentos distintos), configura

17 Vídeos publicitários disponíveis em <http://www.youtube.com/watch?v=aziB8-xFS_o> e em $<$ http://www.youtube.com/watch?v=UalfgJbMWP4> exprimem e caracterizam com fidelidade a região de entorno do Parque Augusto Franco (Parque da Sementeira), bem como demonstram o uso do contexto ambiental daquela localidade para atendimento aos interesses do mercado imobiliário. 
o fato gerador de referido tributo. É possível, então, sua incidência a fim de custear a manutenção do Parque Augusto Franco, sendo esse o primeiro viés sobre uma nova abordagem da contribuição de melhoria.

Ressalta-se que pode haver questionamentos acerca da inadequação deste entendimento, tendo em vista que a jurisprudência recente ${ }^{18}$ exige uma lei específica para cada obra pública. Responde-se, então, da seguinte forma: sob a ótica do Estado de Direito Ambiental, ou referida jurisprudência está presa ao paradigma anterior, que não é capaz de dar respostas à realidade ambiental, ou tais decisões reiteradas foram prolatadas para os casos específicos de construção física de obra pública, nada impedindo que, para cada período de aferição da valorização imobiliária, edite-se uma lei específica, ainda que de manutenção se trate (obra pública em sentido amplo). Não haveria, portanto, incompatibilidade entre tal jurisprudência e a proposta que a presente pesquisa apresenta, sendo necessária, entretanto, uma lei para cada cobrança a ser feita, dada a periodicidade múltipla da contribuição de melhoria, que será explanada mais adiante.

Em tempo, também registra-se que a possível indagação quanto à falta de previsão na lista de obras públicas elencadas pelo DecretoLei $n^{\circ} 195 / 67^{19}$ para os casos de manutenção de um bem público, o que

18 "A cobrança da contribuição de melhoria exige, por aplicação do princípio da legalidade tributária, lei específica para cada obra realizada, não bastando a previsão genérica em Código Tributário Municipal ou Lei Orgânica Municipal". (REsp 1.326.502/RS, $1^{\text {a }}$ T., rel. Min. Ari Pagendler, j. 18-042013).

19 "Art $2^{\circ}$ Será devida a Contribuição de Melhoria, no caso de valorização de imóveis de propriedade privada, em virtude de qualquer das seguintes obras públicas: I - abertura, alargamento, pavimentação, iluminação, arborização, esgotos pluviais e outros melhoramentos de praças e vias públicas; II - construção e ampliação de parques, campos de desportos, pontes, túneis e viadutos; III - construção ou ampliação de sistemas de trânsito rápido inclusive tôdas as obras e edificações necessárias ao funcionamento do sistema; IV - serviços e obras de abastecimento de água potável, esgotos, instalações de redes elétricas, telefônicas, transportes e comunicações em geral ou de suprimento de gás, funiculares, ascensores e instalações de comodidade pública; $\checkmark$ - proteção contra sêcas, inundações, erosão, ressacas, e de saneamento de drenagem em geral, diques, cais, desobstrução de barras, portos e canais, retificação e regularização de cursos d'água e irrigação; VI - construção de estradas de ferro e construção, pavimentação e melhoramento de estradas de rodagem; VII - construção de aeródromos e aeroportos e seus acessos; VIII - aterros e realizações de embelezamento em geral, inclusive desapropriações em desenvolvimento de plano de aspecto paisagístico." (BRASIL, 1967, grifos nossos). 
poderia redundar em entrave à cobrança da contribuição de melhoria, resta superado quando se considera que tal lista é exemplificativa ${ }^{20}$, bastando previsão na lei do ente federativo que cria referido tributo, porquanto em consonância com o art. 145, inciso III, da Constituição Federal de $1988^{21}$.

Ocorrido o fato gerador, definida a base de cálculo (valorização) e aplicada a alíquota, encontra-se o valor do tributo. Entretanto, o artigo 82, caput, do CTN estabelece limites para cobrança, segundo o qual o limite total é o da despesa realizada, e o limite individual é o acréscimo de valor que da obra resultar para cada imóvel beneficiado. Exemplificase:

Suponha-se que os imóveis A e B tenham sofrido valorização em decorrência da obra pública, no valor de $R \$ 200,00$ e $R \$ 250,00$, respectivamente. A contribuição de melhoria foi calculada no valor de $\mathrm{R} \$$ 200,00 para o imóvel A e de $\mathrm{R} \$ 300,00$ para ao imóvel $B$, e o custo total da obra foi de $R \$ 400,00$. Então, não se poderia cobrar $R \$ 500,00$ (R\$ 200 de $A$ mais $R \$ 300,00$ de $B$ ) porque o limite total é de $R \$ 400$, custo total da obra. Também não poderia cobrar $\mathrm{R} \$ 300,00$ de $B$ porque este imóvel foi valorizado em apenas $\mathrm{R} \$ 250,00$, limite individual. Ou seja, os $\mathrm{R} \$ 400$, custo total, seriam cobrados proporcionalmente à valorização decorrida, dentro dos limites de cada um: $\mathrm{R} \$ 177,76$ de $\mathrm{A}$ (equivalente a $44,44 \%$ da soma das duas valorizações) e $R \$ 222,24$ de $B$ (equivalente a $55,56 \%$ da soma das valorizações). Essa é a exegese literal extraída do artigo 82, caput, do CTN (Lei $\left.n^{\circ} 5.172 / 66\right)$.

Ocorre que a Constituição de 1988, ao contrário das anteriores, não estabelece expressamente limites, deixando em aberto os parâmetros de cobrança. Há entendimentos divergentes, entretanto, sobre essa matéria.

20 Cf. Moraes (1996).

21 Vide nota 14. 
Segundo Machado (2008, p. 439):

Aliás, parece-nos que será inconstitucional a norma que, alterando o Código Tributário Nacional, exclua os mencionados limites. É que a contribuição de melhoria, por sua própria natureza específica, não pode ir além da despesa feita com a obra pública, nem do incremento de valor do imóvel respectivo.

Para o autor, os limites total e individual permanecem conforme o estabelecido pelo artigo 82, caput, do Código Tributário Nacional. Já o professor Paulo de Barros Carvalho entende:

Há algo, todavia, que deverá respeitar: o quanto de acréscimo patrimonial individualmente verificado. [...] Extrapassar esse limite representaria ferir, frontalmente, o princípio da capacidade contributiva, substância semântica sobre que se funda a implantação do primado da igualdade, no campo das relações tributárias (CARVALHO, 2011, p. 74).

No entender desse insigne jurista, o único limite a ser respeitado é o individual, correspondente à valorização imobiliária. Não em virtude do CTN, mas em obediência ao princípio constitucional da igualdade, da qual decorre o da capacidade contributiva.

No mesmo sentido Carraza (2011, p. 598-599): "Observamos, por outro lado, que, com a nova Constituição, caiu o limite global de arrecadação da contribuição de melhoria [...] De qualquer modo, o limite individual permanece". Para ele, há que se observar a valorização como limite individual, tendo em vista o principio informador da contribuição de melhoria, conforme Geraldo Ataliba ensina, que é o da proporcionalidade ao benefício especial recebido por uma pessoa em decorrência da obra pública realizada.

A presente pesquisa filia-se à corrente que observa a Constituição Federal como parâmetro, a partir do qual o único limite a ser observado é o quantum de valor foi acrescido ao imóvel. Ou seja, há apenas o limite individual, que é a valorização proporcionada para cada um dos 
imóveis beneficiados pela obra pública, podendo o valor arrecadado ser maior que o valor gasto na manutenção de parques públicos.

Outro aspecto que merece um novo olhar refere-se à periodicidade do fato gerador do contributo legal. Ou seja, deve-se saber se tal fato jurígeno necessariamente ocorre uma única vez. Nesse sentido,

Julgamos importante também deixar assentado que a contribuição de melhoria não é um tributo renovável periodicamente; pelo contrário, só pode ser cobrada uma vez [...] Assim, por exemplo, se uma ponte valoriza o imóvel de "A", este somente poderá ser tributado, em razão desta obra pública, uma vez. É evidente que, se, tempos depois, for erigido, na região, v.g., um viaduto, que torna a valorizar o imóvel de "A", uma nova contribuição de melhoria dele poderá ser cobrada. Só que neste caso, um novo fato imponível terá ocorrido (terá havido uma nova valorização imobiliária, provocada por uma nova obra pública). (CARRAZA, 2011, p. 596)

Vislumbra-se que Carraza (2011), em compasso com a doutrina dominante, entende que ensejaria a cobrança da contribuição de melhoria uma única vez em relação a uma única e determinada obra pública. Parece haver, data maxima venia, um equívoco do referido autor. Retomando os aspectos gerais da contribuição de melhoria, anunciava-se que seu fator gerador é complexivo. Nesse sentido, Rodrigues (2002, p. 117):

[...] poderíamos dizer que a contribuição de melhoria é tributo que depende de um fato complexo para nascer. $\mathrm{O}$ que vem a ser um fato complexo? É, na verdade, o conjunto de fatos interligados por relações causais ou jurídicas que são necessários para que se dê o consequente normativo. A ocorrência de apenas um deles não é suficiente ao nascimento da relação jurídica tributária.

É necessário, pois, o somatório de fatos isolados para que exista o fato gerador. Nesse sentido, se ele é composto por dois elementos (obra pública + valorização), então a alteração de um desses elementos 
corresponde à ocorrência de um novo fato gerador, até porque a realidade social e os fatos econômicos são dinâmicos. "Entendemos que a valorização é um fato social, que ocorre no subsistema dos fatos econômicos" (RODRIGUES, 2002, p. 111). Percebe-se, assim, o caráter não estanque do fato gerador, pois ele pode ocorrer não uma única vez relativamente a uma determina obra pública.

Noutro dizer, se há uma nova valorização decorrente da mesma obra, obviamente houve circunstâncias fáticas diversas geradoras do fato imponível. Por exemplo, na equação matemática $\mathrm{F}_{\mathrm{g}}=\mathrm{O}_{\mathrm{p}}+\mathrm{V}-\mathrm{em}$ que $F_{g}$ é o fato gerador, $O_{p}$ é obra pública e $V$ é a valorização, observase que, sendo $O_{P}$ uma variável constante, qualquer alteração na variável $V$, decorreria um $F_{g}$ diferente. Assim, se $V$ diminuísse, não haveria o que falar em contribuição de melhoria pela ausência da mais-valia. Contudo, se $V$ aumentasse alterar-se-ia $F_{g}$ e como a alteração se deu em razão de mais-valia (acréscimo de valor), ensejaria, então, referido tributo.

Depreende-se daí que a cada nova valorização decorrente especificamente da mesma obra em referência - a qual, na essência, é outra obra, dada a incorporação de novos elementos - há de se operar novamente a hipótese de incidência e, por conseguinte, uma nova obrigação tributária nascida do inédito fato gerador. Tal fenômeno é possível, pois a periodicidade da incidência da contribuição de melhoria pode ocorrer em número de vezes tantos quantos forem a valorização decorrente da manutenção da obra pública Parque Augusto Franco, podendo ser anual, por exemplo, a ocorrência do fato gerador.

Tal conclusão reforça o entendimento acerca do conceito de “obras públicas", na medida em que conduz a dois resultados em relação aos defensores da unicidade de ocorrência do fato gerador da contribuição de melhoria. O primeiro é que o fato gerador não é complexo, ou seja, que basta apenas a construção física da obra pública, e que por isso o fato jurígeno é uno, pois somente se constrói uma vez. Dizendo de outro modo, se se entender que o fato gerador é único, então é porque este se vincula apenas à obra pública (que só é feita uma única vez), desprezando o núcleo do fato jurígeno que é a 
valorização. O segundo resultado, ao contrário, é que o fato gerador é complexo, que seu núcleo é a valorização e que pode ocorrer mais de uma vez. Ora, se o fato gerador pode ocorrer mais de uma vez, e se a construção física só pode ser feita uma vez, então a valorização imobiliária vai decorrer de quê, se não for das condições, elementos e serviços atrelados ao bem público já construído e, portanto, abrangente desse complexo artificial e natural? Dizendo por outra feição, havendo uma segunda valorização imobiliária decorrente de obra pública já construída, então as condições mercadológicas que deram causa a tal acréscimo serão necessariamente incorporadas a tal obra, denotando o caráter amplo da expressão "obras públicas", para fins de contribuição de melhoria.

Além disso, se não é a construção física puramente o fato gerador, e se a ela agrega valor o complexo de elementos integradores, então é possível concluir que a expressão "obras públicas", para fins de incidência de contribuição de melhoria, é toda atividade estatal realizada na construção física de um bem público, bem como a prestação de serviços de manutenção desses bens, inclusive os ecossistêmicos provindos da natureza, tudo em consonância com a nova hermenêutica jurídica e o Estado Ambiental, ficando dependente de comprovação quanto à aferição da valorização imobiliária (em momentos distintos), para efeito de ocorrência do fato gerador e consequente base de cálculo do tributo em comento.

\section{Conclusão}

A Constituição da República Federativa do Brasil de 1988 rege a ordem jurídica do Estado de Direito Ambiental brasileiro. Os fundamentos (a cidadania e a dignidade da pessoa humana) e os objetivos da república (erradicação da pobreza e a marginalização e a redução das desigualdades sociais, bem como a construção de uma sociedade livre, justa e solidária) delineados pela Constituição Federal, aliados aos princípios constitucionais de Direito Ambiental (princípio do meio ambiente ecologicamente equilibrado como direito fundamental da 
pessoa humana; princípio do acesso equitativo aos recursos naturais; e princípio do usuário-pagador, por exemplo) permitem essa primeira conclusão.

Como o Estado Ambiental tem na solidariedade o marco jurídicoconstitucional, e na sustentabilidade o marco axiológico, as normas (princípios e regras) e valores prescritos na Carta Política é que devem pautar a interpretação constitucional mais condizente com a realidade social que se apresenta, que hoje é caracterizada pela complexidade das questões ambientais, mormente as desigualdades sociais evidenciadas na distribuição não equânime dos benefícios e dos ônus ambientais processados na urbe, afetando o direito de acesso à cidade como um todo.

Busca-se assim um novo olhar - que pode ser considerado a quebra de paradigma na compreensão e condução de propostas socialmente sustentáveis, ou menos desiguais - sobre a ordem jurídico-constitucional presente na Carta Magna, para cujos conflitos, demandas e desigualdades sociais provocadas pelo padrão capitalista de apropriação das riquezas, exige-se uma inovadora dinâmica no processo interpretativo normativo. Dessa forma, a interpretação mais consentânea com a Constituição Federal de 1988, mais fiel ao conteúdo material da contribuição de melhoria - equalizador entre distribuição de benesses e ônus financeiros - e de acordo com os novos reclamos das questões ambientais que a modernidade exige, revela que a expressão "obras públicas" não deve ficar restrita aos aspectos de construção física de um bem público. Ao contrário, deve ir além para abarcar situações em que a própria manutenção e o zelo desse bem deem o formato singular ao patrimônio público ambiental, levando-nos a segunda conclusão de que é possível a incidência de contribuição de melhoria sobre a valorização imobiliária decorrente de obra pública já construída (bem público) para custeio dos gastos com sua manutenção. 


\section{Referências}

ALEXY, Robert. Teoria dos direitos fundamentais. Tradução de Virgílio Afonso da Silva. 2. ed. São Paulo: Malheiros, 2011. (Teoria \& direito público).

ARAÚJO, Cláudia Campos de; FERREIRA, Maria Isabel Reis; RODRIGUES, Patrícia Castilho; SANTOS, Simone Marques dos. Meio ambiente e sistema tributário: novas perspectivas. São Paulo: Editora Senac, 2003.

ATALIBA, Geraldo. Hipótese de incidência tributaria. 5. ed. São Paulo: Malheiros, 1996. (Estudos de Direito Tributário).

BANUNAS, loberto Tatsch. Poder de policia ambiental e o município: guia jurídico do gestor municipal ambiental - orientador legal do cidadão ambiental. Porto Alegre: Sulina, 2003.

BARBOSA, Wallace Souza. A contribuição de melhoria como instrumento de concretização do estado de direito ambiental. 2014. 144 f. Dissertação (Mestrado em Desenvolvimento e Meio Ambiente) Universidade Federal de Sergipe, Sergipe, 2014. Disponível em: <http:// bdtd.ufs.br/tde_busca/arquivo.php?codArquivo=1961>. Acesso em: 1 mar. 2014.

BARROSO, Luís Roberto. Interpretação e aplicação da Constituição: fundamentos de uma dogmática constitucional transformadora. 7. ed. rev. São Paulo: Saraiva, 2009.

BECK, Ulrich. Sociedade de risco: rumo a uma outra modernidade. Tradução de Sebastião Nascimento. 2. ed. São Paulo: Ed. 34, 2011.

BELCHIOR, Germana Parente Neiva. Hermenêutica jurídica ambiental. São Paulo: Saraiva, 2011.

BONAVIDES, Paulo. Curso de Direito Constitucional. 8. ed. rev. atual. e ampl. São Paulo: Malheiros, 1999.

BRASIL. Constituição (1988). Constituição da República do Brasil. Brasília: Senado, 1988. 
BRASIL. Código Tributário Nacional. Lei $n^{\circ} 5.172$ de 25 de outubro de 1966. Dispõe sobre o Sistema Tributário Nacional e institui normas gerais de direito tributário aplicáveis à União, Estados e Municípios. Disponível em: <http://www.planalto.gov.br/ccivil_03/leis//5172.htm>. Acesso em: 15 dez. 2013.

BRASIL. Decreto-Lei no 195 de 24 de fevereiro de 1967. Dispõe sobre a cobrança da Contribuição de Melhoria. Disponível em: <http://www. planalto.gov.br/ccivil_03/decreto-lei/Del0195.htm>. Acesso em: 4 dez. 2013.

BRASIL. Política Nacional do Meio Ambiente. Lei n 9.638 de 31 de agosto de 1981. Dispõe sobre a Política Nacional do Meio Ambiente, seus fins e mecanismos de formulação e aplicação, e dá outras providências. Disponível em: <http://www.planalto.gov.br/ccivil_03/leis/ I6938.htm>. Acesso em: 4 dez. 2013.

CANOTILHO, José Joaquim Gomes. Estado constitucional e democracia sustentada. Revista do Centro de Estudos de Direito do Ordenamento, do Urbanismo e do Ambiente, Coimbra, ano IV, p. 9-16, 2001.

CANOTILHO, José Joaquim Gomes; LEITE, José Rubens Morato (Orgs.). Direito constitucional ambiental brasileiro. São Paulo: Saraiva, 2007.

CARRAZA, Roque Antônio. Curso de Direito Constitucional Tributário. 27. ed. rev. ampl. atual. São Paulo: Malheiros, 2011.

CARVALHO, Paulo de Barros. Curso de Direito tributário. 23. ed. São Paulo: Saraiva, 2011.

CELI CONSTRUTORA LTDA. Vídeo publicitário referente ao empreendimento Mansão Sementeira Park. Vídeo digital (4min18s). Disponível em: <http://www.youtube.com/watch?v=aziB8-xFS_o>. Acesso em: 4 dez. 2013.

DALLARI, Dalmo de Abreu. Elementos de teoria geral do Estado. 31. ed. São Paulo: Saraiva, 2012. 
DERANI, Cristiane. Direito ambiental econômico. São Paulo: Max Limonad, 1997.

FEITOSA, André Luís Oliveira; SOUZA, Roberto Rodrigues de. O critério de demarcação de ciência de Karl Popper. In: SANTOS, Antônio Carlos dos; BECKER, Evaldo (Orgs.). Entre o homem e a natureza: abordagens teórico-metodológicas. 1. ed. Porto Alegre: Redes Editora, 2012. p. 91-100.

FFB CONSTRUÇÕES LTDA. Vídeo publicitário referente ao empreendimento Mansão Margarida Diniz. Vídeo digital (3min29s). Disponível em: <http://www.youtube.com/watch?v=UalfgJbMWP4>. Acesso em: 5 dez. 2013.

FRANÇA, Sarah Lúcia Alves. Os condomínios horizontais na zona de expansão urbana de Aracaju: uma nova modalidade de segregação. In: FÁLCON, Maria Lúcia de Oliveira; FRANÇA, Vera Lúcia Alves. (Orgs.). Aracaju: 150 anos de vida urbana. Aracaju: PMA/SEPLAN, 2005, p. 93-117.

GOMES, Carla Amado. Risco e modificação do acto autorizativo concretizador de deveres de protecção do ambiente. 2007. Tese (Doutorado em Direito) - Faculdade de direito da Universidade de Lisboa, Lisboa, 2007. Disponível em: <https://goo.gl/mPLqkU>. Acesso em: 27 fev. 2015.

GOMES, Nestor Castilho. A teoria da norma de Friedrich Müller: reflexos na metódica jurídica. 2009. 132 f. Dissertação (Mestrado em Direito) - Universidade Federal de Santa Catarina, Santa Catarina, 2009. Disponível em: <http://www.dominiopublico.gov.br/download/teste/arqs/ cp094974.pdf>. Acesso em: 27 fev. 2015.

HARTMANNN, Ivar Alberto Martins. E-codemocracia: a proteção ao meio ambiente no ciberespaço. Porto Alegre: Livraria do Advogado Editora, 2010.

JACINTHO, Jussara Maria Moreno Jacintho. Dignidade humana: princípio constitucional. Curitiba: Juruá, 2009. 
KUHN, Thomas Samuel. A estrutura das revoluções científicas. 5. ed. São Paulo: Editora Perspectiva, 1998.

LEITE, José Rubens Morato. Sociedade de risco e Estado. In: CANOTILHO, José Joaquim Gomes; LEITE, José Rubens Morato (Orgs.). Direito constitucional ambiental brasileiro. São Paulo: Saraiva, 2007.

MACHADO, Affonso Leme Machado. Direito ambiental brasileiro. 11. ed. rev. atual. e ampl. São Paulo: Malheiros Editores, 2003.

MACHADO, Hugo de Brito. Curso de Direito tributário. 29. ed. rev. atual. e ampl. São Paulo: Malheiros Editores, 2008.

MAXIMILIANO, Carlos. Hermenêutica e aplicação do Direito. Rio de Janeiro: Forense, 2010.

MAY, Peter H. Avaliação integrada da economia do meio ambiente: propostas conceituais e metodológicas. In: ROMEIRO, Ademar Ribeiro; BASTIAAN, Philip Reydon; LEONARDI, Maria Lúcia [Orgs.]. Economia do meio ambiente: teoria, políticas e a gestão de espaços regionais. 3 ed. Campinas, SP: Unicamp IE, 2001. p. 53-60.

MILARÉ, Édis. Direito do meio ambiente: gestão ambiental em foco: doutrina, jurisprudência, glossário. 6 ed. rev. atual. e ampl. São Paulo: Editora Revista dos Tribunais, 2009.

MODÉ, Fernando Magalhães. Tributação ambiental: a função do tributo na proteção ao meio ambiente. 1. ed. 2. tir. Curitiba: Juruá, 2004.

MORAES, Alexandre de. Direito constitucional. 11. ed. São Paulo: Atlas, 2002.

MORAES, Bernardo Ribeiro de. Compêndio de direito tributário. 5. ed. Rio de Janeiro: Forense, 1996.

PESSOA, Flávia Moreira Guimarães; BARRETO, P. C. Do direito fundamental ao meio ambiente ecologicamente equilibrado à concepção do direito do meio ambiente. Evocati Revista, Aracaju, v. 86, 2013. Disponível em: <http://goo.gl/S17wnq>. Acesso em: 23 fev. 2015. 
PESSOA, Flávia Moreira Guimarães. O embate dos anseios fundamentais de justiça e segurança no raciocínio jurídico. 1. ed. Aracaju: Evocati, 2007. v. 1.

RAWLS, John. Uma teoria da justiça. Tradução de Almiro Pisetta e Lenita M. R. Esteves. São Paulo: Martins Fontes, 1997.

RODRIGUES, Priscila Figueiredo da Cunha. Contribuição de melhoria. São Paulo: Malheiros Editores, 2002.

SALGE JÚNIOR, Durval. Instituição do bem ambiental no Brasil, pela Constituição Federal de 1988: seus reflexos jurídicos ante os bens da União. São Paulo: Juarez de Oliviera, 2003.

SANTOS, Boaventura de Sousa. Para um novo senso comum: a ciência, o direito e a política na transição paradigmática. 7. ed. São Paulo: Cortez, 2009.

SACHS, Ignacy. Desenvolvimento includente, sustentável sustentado. Rio de Janeiro: Garamond, 2008.

SILVA, José Afonso da. Direito ambiental constitucional. 5. ed. São Paulo: Malheiros Editores, 2004.

SILVA, José Afonso da. Curso de Direito constitucional positivo. 34. ed., rev. atual. São Paulo: Malheiros, 2011.

SOUZA, Nadja Christine de Castro. A quem pertence a vista dos rios? A questão estética no meio ambiente urbano e o direito à paisagem hídrica no município de Manaus. In: ENCONTRO PREPARATÓRIO DO CONPEDI/UNICAP, 15., 2006, Recife. Anais... Disponível em: <http:// www.conpedi.org.br/manaus/arquivos/anais/manaus/estado_dir_ povos_najda_de_castro_souza.pdf>>. Acesso em: 20 mar. 2013.

TORRES, Ricardo Lobo. Os direitos humanos e a tributação: imunidade e isonomia. Rio de Janeiro: Renovar, 1995.

Recebido em: 27/03/2014

Aprovado em: 21/10/2014 